\section{DiscoverSys \\ Published by DiscoverSys \\ Pilot project on Global Youth Reproductive Health Program: Implementation in Denpasar City}

\author{
I Gusti Ayu Agung Putri Krismayanthi, ${ }^{1 *}$ Pande Putu Januraga, ${ }^{2}$ \\ Desak Putu Yuli Kurniati
}

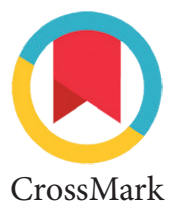

CrossMark

\title{
ABSTRACT
}

Background and purpose: Premarital sexual relations in adolescents and early marriage tends to increase in Indonesia. One of the programs implemented in Indonesia to reduce these problems is the reproductive health program for adolescents in schools. The Youth World Spirit Module or called SEmangaT duniA RemajA (SETARA) is used as a tool for teaching and learning activities in pilot projects in several cities in Indonesia, including Denpasar. This study aims to determine the implementation of the program in Denpasar.

Methods: This study employed a qualitative approach conducted at junior high schools in Denpasar City. Data collection was carried out with six focus group discussions (FGDs) consisting of three FGDs with 20 students aged 13-15 years and three FGDs with 15 teachers who were appointed as a facilitator of the program. In addition, in- depth interviews were also conducted with three junior high school principals. FGDs and in-depth interviews were recorded, transcribed and analysed thematically using the Miles and Huberman Technique. Results: The study showed that the provision of the SETARA module was able to change the impression of taboo and broaden adolescent insights on reproductive health material. The implementation of this module is slightly different between schools due to differences in time allocation, number of activities in schools and the absence of standardised implementation guidelines. However, teachers and schools continue to support the implementation of this module.

Conclusion: This module is quite effective in providing information so as to eliminate the taboo impression from reproductive health material.
${ }^{1}$ Public Health Postgraduate Program, Faculty of Medicine, Udayana University ${ }^{2}$ Department of Public Health and Preventive Medicine, Faculty of Medicine, Udayana University

${ }^{*}$ Correspondence to: I Gusti Ayu Agung Putri Krismayanthi, Public Health Postgraduate Program, Faculty of Medicine, Udayana University pkrismayanthi@gmail.com

Keywords: SETARA, youth, health information, reproductive health Cite This Article: Krismayanthi, I.G.A.A.P., Januraga, P.P., Kurniati, D.P.Y. 2019. Pilot project on Global Youth Reproductive Health Program: Implementation in Denpasar City. Public Health and Preventive Medicine Archive 7(2): 114-120. D0I:10.15562/phpma.v7i2.216

\section{INTRODUCTION}

The Indonesian Demographic and Health Survey (IDHS) or in Indonesia called Survey Demografi dan Kesehatan Indonesia (SDKI) indicates that premarital sex among adolescents is still high and is increasing. In 2012, $0.7 \%$ of women and $4.5 \%$ of men aged 15-19 years had already had premarital sexual relations ${ }^{1}$ and in 2017 it increased to $2 \%$ of women and $8 \%$ of men. ${ }^{2}$ The highest proportion was found at age 17 years (19\%) in both men and women. ${ }^{2}$ Likewise, early marriage among women aged $15-19$ years remains quite high at $13 \%$ in $2012^{1}$ but decreased to $9 \%$ in the 2017 IDHS. ${ }^{2}$

The maternal mortality rate in Indonesia was reported at 390 per 100,000 live births in 1990 and 305 per 100,000 live births in $2015 .^{3}$ The infant mortality rate in Indonesia was reported 68 per 1,000 live births in 1990 and 24 per 1,000 live births in 2017. ${ }^{3}$ Although it has decreased, it is still far from the Sustainable Development Goals (SDGs) target of 2030, which is 70 per 100,000 live births for maternal mortality and 12 per 1,000 live births for infant mortality. ${ }^{4}$ Early age marriages in adolescents contribute significantly to maternal and infant mortality. Children born to mothers under the age of 20 are reported to have the highest risk of experiencing infant mortality under one week of age..$^{5}$ Death of infants under one month is reported to be 1.5 times higher in mothers under 20 years compared to age 20-29 years. ${ }^{5}$ Mothers who marry early also experience a higher risk of death. Adolescent girls who marry less than 15-19 years in low and middle-income countries are at twice the risk of maternal death compared to older women..$^{6-8}$

To reduce maternal and infant mortality rates especially in adolescents, the World Health Organization (WHO) developed a program called Comprehensive Sexuality Education (CSE), which is a curriculum-based teaching and learning process that includes cognitive, emotional, physical and social aspects of sexuality. ${ }^{9}$ Studies showed that CSE contributes to delaying premarital sexual relations, decreases the frequency and number of sexual partners, decreases risk taking, increases condom use and other contraception. ${ }^{10} \mathrm{CSE}$ is also reported to be cost-effective for preventing HIV transmission. ${ }^{9}$ A study conducted in Zambia shows that implementation of CSE succeeded not only in preventing the negative effects of sexual behaviour but also provided space for young people to have discussions on gender and human rights issues and healthy 
relationships without violence. ${ }^{11}$ The effectiveness of the CSE program was also reported in East and South Africa, which shows that the existence of CSE programs in schools is effective in increasing adolescent knowledge about HIV, increasing condom use, increasing pregnancy prevention and increasing the attitudes of adolescent girls to use their reproductive rights such as refusing sexual intercourse to prevent HIV transmission. ${ }^{12} \mathrm{~A}$ study in Nepal shows that CSE implementation which is applied to out of school teenagers reported that the topics taught are still limited to HIV and AIDS and are only taught to adolescents at the third level of "flexible school". ${ }^{13}$

By policy, most countries in the world are committed to implement CSE, but only a few countries implement it on a wide and sustainable scale, ${ }^{10,14}$ while other countries have not been able to implement it. ${ }^{9}$ The Government of Indonesia has implemented reproductive health programs for adolescents, including the youth information and counselling centre or called pusat informasi dan konseling remaja (PIK-R) and generation planning or called generasi berencana (GenRe) with the leading sector National Population and Family Planning Board or called Badan Kependudukan dan Keluarga Berencana Nasional (BKKBN) ${ }^{15}$ and the youth care health service or called pelayanan kesehatan peduli remaja (PKPR) with the leading sector of the Indonesia Ministry of Health. ${ }^{16}$ Indonesian Family Planning Association or called Perkumpulan Keluarga Berencana Indonesia (PKBI) developed adolescent reproductive health programs by adopting the WHO CSE concept. ${ }^{17,18}$ Reports from programs implemented in the City of Jambi and Lampung where adolescent reproductive health programs are part of extracurricular activities in schools, show that students receive a lot of information related to the topic and they also like the teaching methods and media used. ${ }^{19,20}$

Denpasar City was chosen as one of the pilot projects in the Province of Bali. The pilot project was carried out in three junior high schools for 7th and 8th grade students. The pilot project was preceded by a survey conducted by Kita Sayang Remaja (Kisara) PKBI Bali in 2016. The survey was conducted on 1,200 students in 24 schools consisting of eight junior high schools, eight high schools and eight vocational high schools. ${ }^{21}$ The survey showed that 880 students $(66.67 \%)$ claimed to have been dating and of those who had dated, 57 students $(6.48 \%)$ had had vaginal sex and 23 students $(2.61 \%)$ had had anal sex. The average age of sex (anal, vaginal or oral) is 15.4 years and the youngest is 11 years. Only $10.8 \%$ of students have good knowledge about reproductive health and $11.42 \%$ of students about reproductive risk. ${ }^{21}$
In the pilot project in three junior high schools in Denpasar, SETARA was used as a tool for teaching and learning activities. SETARA stands for SEmangaT duniA RemajA which means the spirit of the youths. This intervention provides a comprehensive sex education to junior high school students in order to increase their awareness regarding issues in reproductive health and sexuality. The results and the process of this pilot project, however, remain unknown. This study aims to explore the success as well as obstacles that arise during the program implementation.

\section{METHODS}

This is a qualitative study with an exploratory approach using the Kellogg Logic Model. The model is a visual illustration that is used to monitor and evaluate a program systemically and visually on the relationship between program resources, activities undertaken and the program outputs. ${ }^{22,23}$ The logic model is also used to evaluate domains of evaluation, including implementation (inputs, activities, outputs) and effectiveness (short term, intermediate and long term effects/outcomes). ${ }^{23}$

This study was conducted in three junior high schools in Denpasar consisting of one public junior high school and two private junior high schools. Participants in this study consisted of students aged 13-15 years, teachers appointed as a program facilitator and school principals. The criteria used in recruiting participants are students who have been involved in the learning activities using the SETARA module, and the teachers who appointed as a SETARA facilitator. Data collection was conducted in August and September 2018 by focus group discussions (FGDs) and in-depth interviews. FGDs were conducted six times consisting of three FGDs with students and three FGDs with the teachers. Total participants in this study were 35 people, consisting of 20 students and 12 teachers for the FGDs, and 3 principals for in-depth interviews. Information explored in this study were the students' perception, roles of teachers and facilitators, implementation of the program and its obstacles. The rigour of the data was ensure by using source triangulation (students, teachers and school principals).

The data obtained was recorded and transcribed verbatim and data analysis was performed manually using thematic analysis with the Miles and Huberman Technique. Thematic analysis is the process of identifying patterns or themes qualitatively which begins with the transcription of the results of the FGD and in-depth interviews. Then proceed with skimming to find an overview of the implementation of the pilot project delivered by participants, grouping units/expressions into 
themes or thematic coding and accompanied by the inclusion of quotes that support the information. Furthermore, a synthesis or comparison of the themes with other themes is appropriate in order to find similarities or differences (divergence) of data. There are seven final themes in this study which consisted of selection of teachers as facilitators in the pilot project, learning time for the SETARA Reproductive Health Program, student interest in teaching materials and methods, students' perception of reproductive health concerns before the SETARA pilot project, students perception of reproductive health concerns after the SETARA Pilot Project, SETARA role for teachers and obstacles in the implementation of the pilot project from the perspective of students and teachers.

This study has been approved by the Ethics Committee of the Faculty of Medicine, Udayana University/Sanglah Hospital Denpasar on 2 October 2018.

\section{RESULTS AND DISCUSSION}

\section{Participant Characteristics}

The characteristics of the FGD participants and informants of the in-depth interviews are presented in Table 1 and Table 2. FGDs were conducted in each school and consisted of 6-7 students in each FGD. Students participated in the FGDs consisted of

\section{Table 1 Characteristics of students participated in FGDs}

\begin{tabular}{lccc}
\hline No & Gender & Age (years) & School \\
\hline 1 & Male & 13 & School 2 \\
2 & Male & 13 & School 2 \\
3 & Male & 13 & School 2 \\
4 & Female & 13 & School 2 \\
5 & Female & 12 & School 2 \\
6 & Female & 13 & School 2 \\
7 & Male & 14 & School 2 \\
8 & Female & 14 & School 1 \\
9 & Female & 14 & School 1 \\
10 & Female & 14 & School 1 \\
11 & Male & 14 & School 1 \\
12 & Male & 14 & School 1 \\
13 & Female & 14 & School 1 \\
14 & Male & 14 & School 3 \\
15 & Male & 14 & School 3 \\
16 & Female & 15 & School 3 \\
17 & Female & 14 & School 3 \\
18 & Female & 15 & School 3 \\
19 & Male & 14 & School 3 \\
20 & Female & 14 & School 3 \\
\hline
\end{tabular}

9 boys and 11 girls with an age range of $12-15$ years. FGDs for teachers were conducted three times with a total of 12 participants, with the number of participants for one FGD was between 3-6 people. Teachers participated in the FGDs consisted of one man and eleven women with an age range of 29-54 years. Most teachers held natural sciences in their respective school, while the others held sports, religion, counselling, social sciences, crafts and Indonesian language. In-depth interview participants are the principals of each school consisting of 2 women and 1 man with an age range of 55-63 years. All teachers had received training related to the SETARA Project for 3 days in June 2018.

\section{Selection of teachers as facilitators in the pilot project}

SETARA's pilot reproductive health program was introduced and implemented in 2017 in three junior high schools in Denpasar City. The target of this program is students in grades 7 and 8. In this study, each school has different reasons for choosing teachers as facilitators. Of the three schools, only one included a homeroom teacher as a facilitator, while the other two schools did not. The reasons are shown in the quotes below:

"The reason we chose the homeroom teacher is
because the homeroom teacher has some time.
We are usually given the time by the school
owner's organization. We can usually use the
1 hour lesson time" (female school principal,
interview, school 1) "For natural sciences with reproductive health, it is easy to mainstream because it's related. Also with religious studies they receive education on morality" (female school principal, interview, school 2)

"We usually discuss the process internally first, in order to choose the teacher that may be able to join this program. After that we decide the selected teacher. That's the mechanism we used." (male school principal, interview, school 3)

The above conditions indicate that the selection of teachers as facilitators in each school is not based on program needs and there are no clear criteria. Ideally, there should be a clear criteria in the selection of teachers to become a qualified and effective facilitator. First, the teacher should have the ability to communicate appropriately and not only act as a role model in the learning process (realness). The second is the aspect of prizing, acceptance and trust which means the teacher must be able to show a sense of concern/care and accept the reaction of students both supportive and disruptive. Third is empathy or the teacher's ability to understand 
Table 2 Characteristics of teachers participated in FGDs and principals participated in indepth interviews

\begin{tabular}{lccccc}
\hline No & Occupation & Age (years) & Gender & School & Field of study \\
\hline 1 & Teacher & 58 & Female & School 2 & Natural science \\
2 & Teacher & 51 & Female & School 2 & Religious studies \\
3 & Teacher & 54 & Female & School 2 & Natural science \\
4 & Principal & 55 & Female & School 2 & Natural science \\
5 & Teacher & 30 & Female & School 3 & Sport \\
6 & Teacher & 46 & Female & School 3 & Natural science \\
7 & Teacher & 48 & Female & School 3 & Sport \\
8 & Principal & 61 & Male & School 3 & Natural science \\
9 & Teacher & 52 & Female & School 1 & Natural science \\
10 & Teacher & 58 & Female & School 1 & Social science \\
11 & Teacher & 51 & Male & School 1 & Vocational studies \\
12 & Teacher & 50 & Female & School 1 & Indonesian language \\
13 & Teacher & 29 & Female & School 1 & Sport \\
14 & Teacher & 29 & Female & School 1 & Counselling \\
15 & Principal & 63 & Female & School 1 & Natural science \\
\hline
\end{tabular}

rather than evaluate or judge. The fourth is being attentive or being able to be a good listener and being able to observe facial expressions. The fifth is being knowledgeable or the teacher has knowledge of the material or topic to be delivered and is able to use a variety of teaching strategies. ${ }^{24,25}$ In the pilot project in Denpasar, the selection of teachers does not refer to the five criteria above and only based on the will and field of study held by the teachers.

\section{Learning time for the SETARA Reproductive Health Program}

The FGDs showed that the two schools implemented the SETARA pilot project by inserting the pilot project material according to the available time of the facilitator and other school activities. One other school set a schedule for learning on Saturdays and gave a one class hour, as in the following quotes:

"There is a special time on Saturday...for one hour" (female teacher, FGD, school 1)

"We are constrained because we have a lot of school activities, what is the full educational calendar? Now, when we want to teach the equivalent, our material will not reach the end" (female teacher, FGD, school 3)

"I teach sport, so I try to fit it in but don't always have time" (female teacher, FGD, school 3)

The difference in teaching time in each school results in low coverage of providing material to students. The insertion method is basically a method used to slip information into general subjects so that learning material can be studied from two sides, namely science and character formation. ${ }^{26}$ While viewed in the context of reproductive health learning, the application of this method does not seem appropriate because the SETARA material is a dense material and must be given fully to students in order to avoid misinformation.

\section{Student interest in teaching materials and methods}

Students from all three schools said that they had a high interest in the materials taught in SETARA. If sorted according to students' interests, emotional change material is the material most preferred by students followed by other material namely "the world begins with me", "self-reflection" and HIV/ AIDS. Student interest in emotional change material is because the material is very representative of adolescents who tend to have unstable emotions. According to the confession of one student, after being given the material to change his emotions he became calmer and not as quickly provoked by his emotions as in the following quote.

"Interesting for me, I used to be so moody and angry. But since I was given the emotional change material, I became able to control my emotions, and not be too emotional, right?" (male student, FGD, school 1)

Besides the material, students' sense of interest arises because the teaching methods applied are not as boring as the teaching and learning process in general. Students mentioned that in the SETARA pilot project, the facilitator used a variety of fun teaching methods namely games, case studies, 
sharing experiences, debates and role plays. The use of various teaching methods is believed to increase students' desire to learn and make it easier for students to understand the contents of the material. The various methods used in the SETARA learning process are intended to increase student activity in learning. This is intended so that students are able to dominate learning activities and indirectly encourage students to actively think in finding main ideas, solving problems or in applying what they have just learned into real life. ${ }^{27}$

\section{Students' perception of reproductive health concerns before the SETARA pilot project}

Prior to the SETARA pilot project, male students from all three schools claimed to be more comfortable being open to peers, and female students are happier and more comfortable telling stories to mothers. The topic of conversation is usually related to puberty issues such as menstruation and wet dreams, as in the following quote.

"Like when I got my period. I really didn't know. I went to the bathroom, and I was bleeding and after that my mother said that it was normal and meant I was becoming a woman. She also told me about hygiene and how to clean myself" (female student, FGD, school 1)

In the context of adolescent reproductive health, there is some important basic information given to adolescents such as an introduction to the reproductive system and its functions, preparing adolescents to lead a healthy and responsible reproductive life, developing communication skills and understanding of reproductive rights. ${ }^{28}$ If linked to the statement of the informant above, basically mothers as parents have tried to provide information that they know but are still limited to the topic of menstruation. The results of this study are similar to the two previous studies which showed that communication about reproductive and sexual health issues such as dating, menstruation to postnatal care is generally done by mothers. ${ }^{29,30}$ The role of parents in providing sexual and reproductive health information is not seen in male students, as the following quote.

"Wet dreams also, don't ask as it is embarrassing. So we listen to stories from friends" (male students, FGD, school 2).

The information above shows that the family environment is less supportive and less serious in providing information to boys. These results are consistent with previous study which shows that the presence of peers is considered capable of providing reproductive health information because they have the same gender, age, more openness, trust and comfort. ${ }^{31}$ However other studies have shown that boys are more aggressive in conducting conversations about reproductive health with parents compared to adolescent girls. ${ }^{32}$ Related to this, further studies are needed on the needs of adolescent boys for access to reproductive health information.

\section{Students' perception of reproductive health concerns after the SETARA Pilot Project}

Provision of SETARA material in schools is an effort made to improve adolescent access to reproductive health information. The inclusion of the material has been able to change the way they view reproductive health concerns, and related taboo, as shown in the quote below.

"At first there were only pictures. We knew it was all so taboo, right? But now it's just fine, just laughed" (female student, FGD, school 3)

"It used to be like a dirty topic, something embarrassing...just about the reproductive organs like that. But I have just learned that we also experience a change in emotions, it changed 180 degrees in my mind" (male student, FGD, school 1)

In this study, students felt that the loss of taboo, dirty and vulgar impressions on reproductive health topics could not be separated from the role of the teacher who was able to deliver the material. Provision of material using a variety of teaching methods can create a comfortable impression for students to want to interact with peers even though they are of different sex. The inclusion of basic material such as "the world begins with me", "emotional changes" and "your body changes", is a positive step in opening teenage insights and their mindset to reproductive health. The ability of teachers to use a variety of interesting learning methods, the use of language or adolescent terms is also one of the things that causes a change in the way students look at it. ${ }^{33}$

\section{SETARA role for teachers}

The implementation of the pilot project in three schools was also considered by the teachers as a positive approach in introducing reproductive health not only to students as the main target, but also to those involved as facilitators. For teachers, the implementation of this pilot project provides a new perspective in an effort to reach teenage students. The various methods of approach in the module indirectly bring the relationship between teacher and student closer. This can be seen from the following quote.

"Children are more open with their teachers. Now they like to share their personal problems with me. They trust me" (female teacher, FGD, school 3) 
"It is important for us to learn their slang, understand what they are going through. It means that if we enter their world, they won't be awkward with us anymore" (female teacher, FGD, school 1)

These results show that SETARA has an influence on the teacher's role in building emotional relationships and openness with students. As a facilitator, an aspect needs to be emphasized is the establishment of a personal relationship between the teacher and students, helping/facilitating students in the learning process to involve students playing an active role when solving problems. . $^{25,34}$ The students openness occurs as the result of the teachers ability to apply teaching methods that not only involve cognitive aspect but also personal and critical aspects needed by adolescents. ${ }^{35,36}$

\section{Obstacles in the implementation of the pilot project from the perspective of students and teachers}

Although module learning has a positive impact on students and teachers, there are still some obstacles in the implementation. The students mentioned that high number of school activities is one of the obstacles in implementing the pilot project in their school as conveyed by the FGD participants below.

"There are so many school activities. Like for example the school birthday. Many students were involved. It's useless for teachers to teach only 11 students. It needs to be everyone" (female students, FGD, school 3)

Meanwhile according to the teachers, the obstacles in the implementation of SETARA, such as the module material, cannot be taught fully as the curriculum is already very dense.

"The problem is we have so much to cover already in the school curriculum, it is impossible to cover all the SETARA material" (female teacher, FGD, school 2)

Another barrier to implement the pilot project is the difference in the portion of teaching between schools because there is no specific time allocation. This condition also occurs due to the absence of implementation guidelines governing the number of hours and meetings in one week, as stated by the FGD participant below.

"We are different from other schools. We have provided particular hours and facilitated the school to choose the time. Whereas other schools with pilot projects are still confused about where to look for hours, they have to put them in" (female teacher, FGD, school 1)
The above obstacles show that there is a lack of readiness of schools in implementing the pilot projects. The preparation of schools, teachers and students in the SETARA pilot project must be considered. The inclusion of reproductive health material in schools results in the increase of teaching burden. Therefore, it is necessary to choose the right time in order to avoid interference with the facilitators' teaching and learning activities.

Our study shows that most teachers agree that the material is appropriate for the development of adolescents in the future, but it should also be noted that this pilot project uses a varied approach when compared to the conventional learning process. The demand for interactive learning between students and their peers and between students and teachers results in the need for special time allocation. Failures often occur in the implementation of activities or programs, one of which is caused by inadequate human resources, incompetence in their fields and lack of facilities and infrastructure to support the success of the program. ${ }^{37}$ This study shows that the obstacles during implementation occurred due to the low support from school management and the principal in preparing for this activity. The strategy that needs to be emphasized in increasing the success of the pilot project is the bottom-up approach in order to ensure active participation of all stakeholders. ${ }^{38}$

The limitation of this study is that some aspects were not explored in-depth, which resulted in the lack of understanding regarding the selection process of the program facilitators and how their characteristics influence their motivation and roles in implementing the program.

\section{CONCLUSION}

The implementation of the SETARA pilot project varies between schools in terms of facilitator selection and time allocated for the teaching-learning activities. Changes in students' perspective and decrease of taboo impressions occur since the pilot project was implemented. The pilot project also plays a role in building relationships between students and teachers, making it easier for teachers to supervise students' interaction with their peers. In order to increase the effectiveness of the program, implementation guidelines is required to govern the criteria for selecting facilitators and allocation of teaching-learning time.

\section{ACKNOWLEDGEMENTS}

We would like to thank all participants in this study, Principal of Denpasar 6 Public Middle School, Sanur Wisata Middle School, Denpasar Saraswati 
Middle School and Kisara Program Coordinator of Indonesia Family Planning Association for supporting and facilitating the implementation of this study.

\section{REFERENCES}

1. National Population and Family Planning Board. Survei Demografi dan Kesehatan Indonesia 2012 [The 2012 Indonesia Demography and Health Survey]. Jakarta: National Population and Family Planning Board; 2013.

2. National Population and Family Planning Board. Survei Demografi dan Kesehatan Indonesia: Kesehatan reproduksi remaja 2017 [The 2017 Indonesia Demography and Health Survey: Adolescents reproductive health]. Jakarta: National Population and Family Planning Board; 2018.

3. Indonesia Ministry of Health. Profil Kesehatan Indonesia [Indonesia Health Profile]. Jakarta: Indonesia Ministry of Health; 2017.

4. The United Nations. Final list of proposed Sustainable Development Goal indicators. The United Nations; 2016.

5. The United Nations Children's Fund. Levels \& trends in child mortality. USA: The United Nations Children's Fund; 2018.

6. The United Nations Population Fund. Motherhood in childhood: facing the challenge of adolescent pregnancy. USA: The United Nations Children's Fund; 2013.

7. World Health Organization. Early marriages , adolescent and young pregnancies. Geneva: World Health Organization; 2011.

8. World Health Organization. Adolescent pregnancy fact sheet. Geneva: World Health Organization; 2014.

9. World Health Organization. WHO recommendations on adolescent sexual and reproductive health and rights. Geneva: World Health Organization; 2018.

10. UNESCO. International technical guidance on sexuality education. Paris: UNESCO; 2018.

11. UNAIDS. Comprehensive sexuality eduation in Zambia. Geneva: UNAIDS; 2016.

12. The United Nations Population Fund. How effective is comprehensive sexuality education in preventing HIV? USA: The United Nations Population Fund; 2016.

13. The United Nations Population Fund. UNFPA operational guidance for comprehensive sexuality education: a focus on human rights and gender. USA: The United Nations Population Fund; 2014.

14. UNESCO. Emerging evidence, lessons and practice in comprehensive sexuality education-a global review. Paris: UNESCO; 2015

15. National Population and Family Planning Board. Pedoman pengelolaan pusat informasi dan konseling remaja dan mahasiswa (PIK R/M) [Guidelines on the management of the center for youth and university students information and counseling]. Jakarta: National Population and Family Planning Board; 2012.

16. Indonesia Ministry of Health. Pedoman Pelayanan Kesehatan Reproduksi Terpadu di Tingkat Pelayanan Dasar. Jakarta: Indonesia Ministry of Health; 2015.

17. Rutgers WPF Indonesia. Laporan tahunan 2012 [The 2012 annual report]. Jakarta: Rutgers WPF Indonesia; 2012.

18. Rutgers WPF Indonesia. Comprehensive sexuality education. Jakarta: 2015 [cited 2019 September 23]. Available from: http://www.rutgerswpfindo.org/id/kegiatan-kami/ comprehensive-sexuality-education.

19. Lala H. Evaluasi program kesehatan reproduksi remaja "DAKU!" (Dunia Remajaku Seru) di SMU [Evaluation of an adolescents reproductive health program, "DAKU" (Dunia Remajaku Seru)]. Jurnal Pendidikan Sains. 2015;3(2):90-97.

20. Pakasi DT, Kartikawati R. Antara kebutuhan dan tabu: Pendidikan seksualitas dan kesehatan reproduksi bagi remaja di SMA [Between the need and taboo: Education of sexuality and reproductive health for adolescents in high schools]. Makara Seri Kesehatan. 2013:17(2);79-87.
21. KISARA PKBI Bali. Gambaran pengetahuan, sikap dan perilaku tentang kesehatan reproduksi dan seksual pada remaja Kota Denpasar [Knowledge, attitude and behavior on sexual and reproductive health among youths in Denpasar City]. 2017 [cited: 2018 February 2). Available from: http://www.kisara.or.id/about/pkbi-bali.

22. Abdi S, Mensah G. Focus on: Logic model-A planning and evaluation tool. Ontario; 2016

23. W.K. Kellogg Foundation. Logic model development guide. Michigan; 2004.

24. Wittmer J, Myrick RD. The teacher as facilitator. Virginia: Educational Media Corporation; 1989.

25. Bernaus M. Teaching vs Facilitating. 2016.

26. Murtadlo Z. Kumpulan metode pembelajaran kreatif dan inovatif [Creative and innovative learning methods]. Sarana Tutorial Nurani Sejahtera; 2016.

27. Baharun H. Penerapan pembelajaran active learning untuk meningkatkan hasil belajar siswa di madrasah [The implementation of active learning to increase the study outcome of students at the islamic schools]. Jurnal Pendidikan Pedagogik. 2015;1(1): 34-46.

28. Adjie JMS. Kesehatan reproduksi remaja dalam aspek sosial. Indonesian Pediatric Society. 2013 [cited 2019 September 20]. Available from: http:// www.idai.or.id/artikel/seputar-kesehatan-anak/ kesehatan-reproduksi-remaja-dalam-aspek-sosial.

29. Iliyasu Z, Aliyu MH, Abubakar IS, Galadanci HS. Sexual and reproductive health communication between mothers and their adolescent daughters in Northern Nigeria. Health Care Women International. 2012;33(2):138-152.

30. Wilson EK, Koo HP. Mothers, fathers, sons and daughters: gender differences in factors associated with parent-child communication about sexual topics. Reproductive Health. 2010;7:31.

31. Byron P. Friendship, sexual intimacy and young people's negotiations of sexual health. Culture, Health and Sexuality. 2017;19(4):486-500.

32. Tesso DW, Fantahun MA, Enquselassie F. Parent-young people communication about sexual and reproductive health in E/Wollega zone, West Ethiopia: Implications for interventions. Reproductive Health. 2012;9:13.

33. Rural Health Information Hub. Health Communication. 2016 [cited 2018 February 25]. Available from: https:// www.ruralhealthinfo.org/community-health/health-promotion/2/ strategies/health-communication.

34. Rogers C. Facilitation Theory. [cited: 2019 July 14]. Available from: https://www.learning-theories.org/doku. php?id=instructional_design:facilitation_theory.

35. Haberland N, Rogow D. Sexuality education: Emerging trends in evidence and practice. The Journal of Adolescent Health. 2015;56(1 Suppl): S15-S21.

36. Wanje G, Masese L, Avuvika E, Baghazal A, Omoni G and McClelland RS. Parents' and teachers' views on sexual health education and screening for sexually transmitted infections among in-school adolescent girls in Kenya: a qualitative study. Reproductive Health. 2017;14(95):1-11.

37. Hermiyanty, Hasanah, Setiawan H. Implementasi pendidikan kesehatan reproduksi remaja dalam kurikulum pendidikan jasmani olahraga dan kesehatan di sekolah menengah atas Kota Palu [The implementation of adolescent reproductive health education in the sport and health curriculum at the senior high schools, Palu City]. Jurnal Kesehatan Tadulako. 2016;2(1):45-57.

38. Widyaningrum R, Sitaresmi MN, Lusmilasari L. Evaluasi program trias usaha kesehatan sekolah dan perilaku hidup bersih dan sehat di sekolah luar biasa Bantul [Evaluation of three school health programs and clean and healthy behavior at a special school in Bantul]. BKM Journal of Community Medicine and Public Health. 2016;32(9):309-316.

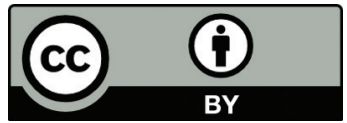

This work is licensed under a Creative Commons Attribution 